\title{
Full Replacement of 2-Mercaptoethanol by Cysteine Plus Selenium Compounds in Augmenting DNA Synthesis of Mitogen-Stimulated Mouse Spleen Lymphocytes
}

\author{
Tetsuro Ishii*, Yoshiki Sugita and Shiro Bannai \\ Institute of Basic Medical Sciences, University of Tsukuba, Tsukuba-shi, \\ Ibaraki-ken 305, Japan
}

\begin{abstract}
Mouse spleen lymphocytes require 2-mercaptoethanol for maximal mitogenic activation in vitro. Previous studies indicate that the lymphocytes are defective in the cystine transport activity and that they require 2mercaptoethanol to utilize cystine. 2-Mercaptoethanol catalytically carries cysteine moiety into the cells in a mixed disulfide form. Because cysteine is easily oxidized to cystine in the culture medium, it has been not easy to precisely examine the effect of near-physiological concentrations of cysteine on the activation of lymphocytes. By controlling the cysteine content in the medium, we have reviewed the effect of cysteine to see if cysteine replaces 2-mercaptoethanol in enhancing the DNA synthesis of lipopolysaccharide-stimulated lymphocytes. It was found that cysteine was less effective than 2-mercaptoethanol, and that cysteine fully replaced 2 -mercaptoethanol when a selenium compound was supplemented. The effects of cysteine and selenium compounds were apparently independent and additive. Among the selenium compounds examined, sodium selenite and L-selenocystine were much more effective in stimulating DNA synthesis than sodium selenate and L-selenomethionine.
\end{abstract}

Click et al. (7) and Chen and Hirsch (6) showed that 2-mercaptoethanol (2ME) markedly enhanced the immune responses of mouse spleen lymphocytes in vitro. Then, Broom et al. (3) showed that many mouse neoplastic lymphoid cells also required $2 \mathrm{ME}$ for cell growth in vitro. As a result of these studies, $10-50 \mu \mathrm{M}$ of $2 \mathrm{ME}$ has been routinely added to the culture media to enhance growth of murine lymphoid cells in vitro. We attempted to replace $2 \mathrm{ME}$ by various physiological substances to understand the physiological meaning of the effect of $2 \mathrm{ME}$. We previously showed that in mouse lymphoma L1210 cells, near-physiological concentrations of cysteine enhanced cellular GSH content and growth of L1210 cells to the same extent as $2 \mathrm{ME}(14,16,17)$. This was based on the facts that $2 \mathrm{ME}$-dependent cells required cysteine because they had a low cystine transport activity $(12,14)$ and that $2 \mathrm{ME}$ catalytically carried cysteine into cells at a high rate in a mixed disulfide form via the system(s) shared by neutral amino acids with bulky side chains, such as leucine and phenylalanine (15). It should be noted that in normal culture media, cystine but not cysteine, is available because cysteine is easily oxidized to cystine in

\footnotetext{
Abbreviations used: 2ME, 2-mercaptoethanol; GSH, glutathione; BCS, bathocuproinedisulfonate; LPS, lipopolysaccharide; Con A, concanavalin A; GSHPx, glutathione peroxidase.

* To whom reprint requests/correspondence should be addressed.
} 
the media, although cysteine is maintained in body fluid.

In mouse spleen lymphocytes, $2 \mathrm{ME}$ also improved the availability of cystine (4, $25,26)$ and thereby $2 \mathrm{ME}$ increased cellular glutathione (GSH) (35), a major metabolite of cysteine. Compared with $2 \mathrm{ME}$, cysteine may be a more important physiological immunomodulator because the cysteine transport activity increases in the lymphocytes during their stimulation with mitogens (18), and macrophages have the ability to produce cysteine (34). The question which we investigate in this paper is whether cysteine fully replaces $2 \mathrm{ME}$ in enhancing DNA synthesis of the mitogenstimulated lymphocytes. Although supplementing cysteine to culture media enhanced the immune responses in vitro $(8,11,25)$, the above question was not accurately answered because of the instability of the cysteine supplemented to the culture media. Controlling the cysteine content, we have shown that cysteine is less effective than 2ME in enhancing DNA synthesis of the mitogen-stimulated lymphocytes in contrast to the growth of L1210 cells. We have found, however, that infusing selenium compounds in addition to cysteine enhanced the DNA synthesis to be as effective as $2 \mathrm{ME}$. The results herein indicate that an antioxidative activity of $2 \mathrm{ME}$ other than enhancing cellular GSH is also important for maximal proliferation of the mitogen-stimulated lymphocytes in vitro.

\section{MATERIALS AND METHODS}

Materials. The materials used in this work were as follows: [methyl- ${ }^{3} \mathrm{H}$ ]-thymidine $(20.0 \mathrm{Ci} / \mathrm{mmol})$, New England Nuclear, Boston, MA; Ficoll-Paque, Pharmacia Fine Chemicals, Uppsala, Sweden; RPMI 1640 medium, Gibco Lab., Grand Island, NY; Lipopolysaccharide (LPS) (W, S. typhosa 0901), Difco Lab., Detroit, MI; 4,7-diphenyl-2,9dimethyl-1, 10-phenanthroline disulfonic acid disodium salt (bathocuproinedisulfonate, BCS), Dojindo Lab., Kumamoto, Japan; L-selenomethionine, Sigma, St. Louis, MO; sodium selenite, sodium selenate, and L-cysteine (free base), Wako Pharmaceutical Company, Osaka, Japan. The majority of the fetal bovine serum used in this study was from Commonwealth Serum Lab. (lot No. 279-2), Melbourne, Australia. An additional 14 lots of fetal bovine sera used were from Commonwealth Serum Lab., Filtron (Victoria, Australia), Flow Lab. (McLean, VI), M.A. Bioproducts (Walkersiuille, MD), and K.C. Biological (Lenexa, KA). $a$-Tocopherol was provided by Eisai Tsukuba Research Lab., (Ibaraki, Japan). Enzymatically synthesized L-selenocystine (9) was provided by Dr. K. Soda (Kyoto Univ.).

Cell preparations and cultures. Both sexes of C57BL/6N mice (Doken Lab., Ibaraki, Japan), ranging in age from 8 to 12 weeks, were used. The mice were fed a commercial diet (MF, Oriental Yeast Co., Tokyo, Japan) containing $0.46 \mathrm{ppm}$ selenium. Mouse spleens (usually one or two) were squeezed between frosted microslide glass in the culture medium, and the cell suspension was allowed to stand in a plastic tube for a few minutes in order to sediment large tissue aggregates. Then, the upper cell suspension was layered on Ficoll-Paque and centrifuged. After centrifugation, the lymphocyte fraction was separated and the cells were washed three times in a serum-free culture medium. The medium used for the cell preparation and culture was RPMI 1640 medium supplemented with $10 \%$ heat-inactivated $\left(56^{\circ} \mathrm{C}\right.$ for $\left.30 \mathrm{~min}\right)$ fetal bovine serum, $1 \mathrm{mM}$ pyruvate, penicillin $(50 \mathrm{units} / \mathrm{ml})$ and streptomycin $(50 \mu \mathrm{g} / \mathrm{ml})$. The lymphocytes thus fractionated were suspended in the complete culture medium, and after the cell density was adjusted to $10^{6}$ cells $/ \mathrm{ml}, \mathrm{LPS}(10 \mu \mathrm{g} / \mathrm{ml})$ was added and seeded in culture plates or flasks. The cells were cultured in an atmosphere of $95 \%$ air and $5 \% \mathrm{CO}_{2}$ at $37^{\circ} \mathrm{C}$. The number of cells were counted using a hemocytometer. The viability of the cells was estimated by the nigrosine $(0.05 \%)$ exclusion method. 
Assays. For assays of $\left[{ }^{3} \mathrm{H}\right]$ thymidine incorporation, triplicate cultures were set up in flatbottom, 24-well plates with a total volume of $1.0 \mathrm{ml}\left(1.0 \times 10^{6}\right.$ cells $)$ per well. Supplements such as cysteine, BCS, selenium compounds and $2 \mathrm{ME}$ were added to each well at the initiation of the culture. The stock solutions ( 10 or $100 \mathrm{mM}$ cysteine, $2 \mathrm{mM} \mathrm{BCS}$, and $10 \mathrm{mM} 2 \mathrm{ME}$ in distilled water) were maintained at $-20^{\circ} \mathrm{C}$. In some experiments, cysteine was added at 8or 12-h intervals starting at time 0. GSHPx and other enzymes were dissolved in the culture medium and filtered for sterilization. $a$-Tocopherol was first solubilized with ethanol and filtered for sterilization after dilution with fetal bovine serum. At the indicated time, 0.2 or $1 \mu \mathrm{Ci}$ of $\left[{ }^{3} \mathrm{H}\right]$ thymidine (diluted with unlabeled thymidine to 0.4 or $2 \mathrm{Ci} / \mathrm{mmol}$ ) was added to each well. After $1 \mathrm{~h}, 10 \mu \mathrm{l}$ of $50 \mathrm{mM}$ thymidine was added to each well, then the culture plate was cooled on ice, and the cells were collected on glass fiber filters in order to determine the amount of ${ }^{3} \mathrm{H}$ incorporated into trichloroacetic acid-insoluble material. Since the amount of radioactivity incorporated into the cells differed from experiment to experiment, standardization of the results was necessary to assess the effect of the supplements. Therefore, in each assay, the percent of radioactivity of the control condition, in which $20 \mu \mathrm{M} 2 \mathrm{ME}$ was added for each experiment, was calculated.

Glutathione peroxidase (GSHPx) activity was assayed at $25^{\circ} \mathrm{C}$ by the method of Paglia and Valentine (27) with hydrogen peroxide as the substrate. The assay mixture contained $61 \mathrm{mM}$ phosphate buffer (pH 7.0), 2.4 mM EDTA, $1 \mathrm{mM} \mathrm{GSH,} 0.2 \mathrm{mM} \mathrm{H}_{2} \mathrm{O}_{2}, 0.16 \mathrm{mM}$ NADPH, $1 \mathrm{mM} \mathrm{NaN}$, and $0.12 \mathrm{U} / \mathrm{ml}$ glutathione-reductase. Lymphocytes were washed twice with cold phosphate buffered saline and then frozen once at $-20^{\circ} \mathrm{C}$. On thawing, the samples were treated with $2.5 \mathrm{mg} / \mathrm{ml}$ digitonin (13), sonicated in an ice-cold bath, and centrifuged at $3000 \mathrm{rpm}$ for $10 \mathrm{~min}$. The supernatant fractions were assayed for GSHPx activity and protein content by the method of Lowry et al. (21). Trichloroacetic acid-soluble thiol contents in the culture media were determined by 5,5'-dithiobis(2-nitrobenzoic acid) using cysteine as the standard, as described in a previous paper (18). Selenium contents of some of the sera were determined by an atomic absorption method. $a$-Tocopherol contents of the sera were determined by the method of Abe and Katsui (1).

\section{RESULTS}

Effect of cysteine and BCS on DNA synthesis. It was not clear whether physiological concentrations of cysteine could fully replace $2 \mathrm{ME}$ in enhancing DNA synthesis of mitogen-stimulated mouse spleen lymphocytes. In order to answer this question, the effect of cysteine on the time-dependent incorporation of $\left[{ }^{3} \mathrm{H}\right]$ thymidine into the cells was compared with that of $2 \mathrm{ME}$ as shown in Fig. 1. In this assay, the freshly prepared lymphocytes were stimulated with LPS, and the incorporation of $\left[{ }^{3} \mathrm{H}\right]$ thymidine was measured by $1 \mathrm{~h}$-pulse labeling at $23,35,47$, and $59 \mathrm{~h}$ in culture. Adding $100 \mu \mathrm{M}$ of cysteine to the medium every $12 \mathrm{~h}$ significantly enhanced the incorporation of $\left[{ }^{3} \mathrm{H}\right]$ thymidine. However, cysteine thus added was far less effective than $20 \mu \mathrm{M} 2 \mathrm{ME}$ added only once at the initiation of the culture. The effect of cysteine was enhanced by $20 \mu \mathrm{M}$ BCS, a nontoxic copper-specific chelating agent which improves the stability of cysteine in the culture medium (18, 24). However, cysteine plus BCS was still far less effective than $2 \mathrm{ME}$, especially after $47 \mathrm{~h}$.

Table 1 compares the effects of various concentrations of cysteine and various time schedules of cysteine addition on the $\left[{ }^{3} \mathrm{H}\right]$ thymidine incorporation. In this table, the contents of nonprotein thiols (presumably cysteine) in the culture medium in some experiments at 23 and $47 \mathrm{~h}$ are also shown so that approximate cysteine con- 


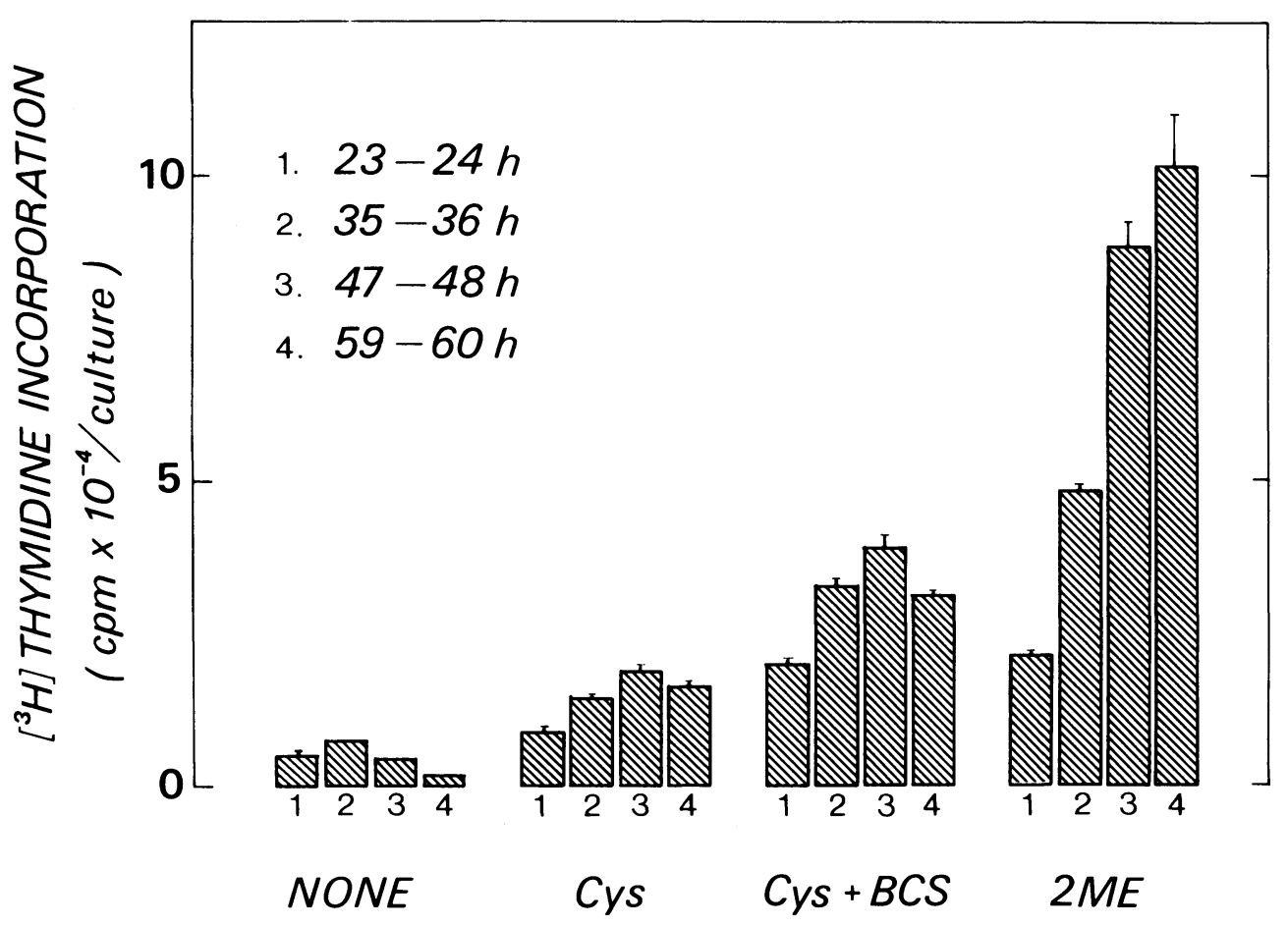

Fig. 1. Effects of the culture supplements on the time-dependent incorporation of $\left[{ }^{3} \mathrm{H}\right]$ thymidine. Cysteine $(100 \mu \mathrm{M})$ was added at $0,12,24,36$ and $48 \mathrm{~h}$. BCS $(20 \mu \mathrm{M})$ and $2 \mathrm{ME}(20 \mu \mathrm{M})$ were added at time 0 . The cultures were exposed to $1 \mu \mathrm{Ci}\left[{ }^{3} \mathrm{H}\right]$ thymidine $(2 \mathrm{Ci} / \mathrm{mmol})$ for $1 \mathrm{~h}$, as indicated.

centrations can be estimated. To maintain near-physiological levels of cysteine in the medium, $100 \mu \mathrm{M}$ cysteine had to be added every $8 \mathrm{~h}$. Cysteine thus added had enhancing effects comparable to that of $2 \mathrm{ME}$ (control) on the first day (23-24 h); however, these effects decreased to roughly $50 \%$ of that of $2 \mathrm{ME}$ on the second day $(47-48 \mathrm{~h})$. When $3 \mathrm{mM}$ cysteine was added at the initiation of the culture, the incorporated $\left[{ }^{3} \mathrm{H}\right]$ thymidine at $47 \mathrm{~h}$ was $50 \%$ of that of the control. Adding $100 \mu \mathrm{M}$ cysteine every $12 \mathrm{~h}$, or $1 \mathrm{mM}$ cysteine at the initiation of the culture, was less effective than the above conditions of cysteine supply. In the presence of BCS, the oxidation of the added cysteine was inhibited and the effect of cysteine was enhanced. However, the effect of cysteine plus BCS was roughly $50 \%$ of that of $2 \mathrm{ME}$ on the second day $(47-48 \mathrm{~h})$. BCS did not enhance the effect of $2 \mathrm{ME}$ on the $\left[{ }^{3} \mathrm{H}\right]$ thymidine incorporation. In conclusion, cysteine with or without BCS under various concentrations could not enhance the DNA synthesis as effectively as $2 \mathrm{ME}$ on the second day of the culture.

Effects of selenium compounds on DNA synthesis. Examining the reason why cysteine was less effective than $2 \mathrm{ME}$, we found that various selenium compounds added to the culture medium enhanced the $\left[{ }^{3} \mathrm{H}\right]$ thymidine incorporation. Figure 2 shows the effects of inorganic selenium compounds, sodium selenite and sodium selenate, on the $\left[{ }^{3} \mathrm{H}\right]$ thymidine incorporation at $47 \mathrm{~h}$. In the presence of cysteine $(100 \mu \mathrm{M} /$ every $12 \mathrm{~h})$ and BCS, selenite at $10^{-7}$ to $10^{-6} \mathrm{M}$ and selenate above $5 \times 10^{-6} \mathrm{M}$ showed maximal effects (nearly equal to $2 \mathrm{ME}$ ), suggesting that selenite was more 
TABLE 1. EFFECTS OF CYSTEINE AND 2-MERCAPtoethanol (2ME) IN THE PRESENCE OR ABSENCE OF BATHOCUPROINEDISULFONATE (BCS) ON THE DNA SYNTHESIS AND ON THE NONPROTEIN THIOL CONTENTS IN THE CULTURE MEDIUM OF THE LPS-STIMULATED LYMPHOCYTES

\begin{tabular}{|c|c|c|c|c|}
\hline \multirow{2}{*}{ Supplements } & \multicolumn{2}{|c|}{$\begin{array}{c}\left.{ }^{3} \mathrm{H}\right] \text { Thymidine Incorporation } \\
1 \mathrm{~h} \text {-pulse label }\end{array}$} & \multicolumn{2}{|c|}{$\begin{array}{l}\text { Non-protein } \\
\text { Thiols in the Medium }\end{array}$} \\
\hline & $\begin{array}{l}23-24 \mathrm{~h} \\
(\% \mathrm{cpm} \text { of }\end{array}$ & $\begin{array}{r}47-48 h \\
\text { each control) }\end{array}$ & at $23 \mathrm{~h}$ & $(\mu \mathrm{M})^{\text {at } 47 \mathrm{~h}}$ \\
\hline \multicolumn{5}{|l|}{ (Without BCS) } \\
\hline $2 \mathrm{ME}(20 \mu \mathrm{M})$ & 100 (control) $^{\mathrm{a}}$ & 100 (control) $^{b}$ & 4 & $7.0 \pm 2.0(n=3)$ \\
\hline None & $25.0 \pm 2.2(n=3)$ & $6.9 \pm 3.2(n=11)$ & 3 & $5.5 \pm 1.3(n=4)$ \\
\hline Cys $(100 \mu \mathrm{M} /$ every $8 \mathrm{~h})$ & 93 & 51 & 9 & 12 \\
\hline Cys $(100 \mu \mathrm{M} /$ every $12 \mathrm{~h})$ & 37 & 21,16 & & \\
\hline Cys (1 mM) & & 21 & & 10 \\
\hline Cys (3 mM) & & 50 & & 20 \\
\hline \multicolumn{5}{|l|}{ (With $20 \mu \mathrm{M}$ BCS) } \\
\hline $2 \mathrm{ME}(20 \mu \mathrm{M})$ & & 100 & & 27 \\
\hline None & & $18.4 \pm 8.3(n=5)$ & 9 & $7.7 \pm 2.5(n=3)$ \\
\hline Cys $(25 \mu \mathrm{M} /$ at $4 \mathrm{~h}$ and every $8 \mathrm{~h})$ & 93 & 54 & 15 & 26 \\
\hline Cys $(50 \mu \mathrm{M}$ /every $8 \mathrm{~h})$ & 123 & $49.6 \pm 7.6(n=5)$ & 31 & 46,35 \\
\hline Cys $(50 \mu \mathrm{M} /$ every $12 \mathrm{~h})$ & 97 & 32 & & \\
\hline Cys $(100 \mu \mathrm{M} /$ every $12 \mathrm{~h})$ & 82 & $46.6 \pm 7.3(n=12)$ & & 36 \\
\hline Cys $(500 \mu \mathrm{M})$ & & 53 & & 24 \\
\hline
\end{tabular}

One million fresh lymphocytes were cultured in one $\mathrm{ml}$ medium with LPS $(10 \mu \mathrm{g} / \mathrm{ml})$ and the supplements indicated. Values are the mean of triplicate assays or the mean of more than three independent experiments \pm SEM.

${ }^{a}$ The incorporated radioactivities in the controls were, on average, $26.8 \pm 4.4(n=5)$ percent of those in the controls labeled between 47 and $48 \mathrm{~h}$.

b The incorporated radioactivities in the controls labeled with $0.2 \mu \mathrm{Ci}\left[{ }^{3} \mathrm{H}\right]$ thymidine $(0.4 \mathrm{Ci} / \mathrm{mmol})$ varied in each experiment between $21890 \pm 1233$ and $42180 \pm 1987 \mathrm{cpms}$ per culture.

c Cysteine $(25 \mu \mathrm{M})$ was added at $0,4,8,16,24,32$, and $40 \mathrm{~h}$.

than one order of magnitude effective than selenate. Without additions of cysteine and $\mathrm{BCS}$, selenite above $5 \times 10^{-8} \mathrm{M}$ and selenate above $5 \times 10^{-6} \mathrm{M}$ significantly enhanced the $\left[{ }^{3} \mathrm{H}\right]$ thymidine incorporation. The effects of cysteine plus BCS and the selenium compounds appear to be additive under these assay conditions. Selenite was cytotoxic above $5 \times 10^{-6} \mathrm{M}$ if cysteine plus BCS was present.

Figure 3 shows the effects of organic selenium compounds, L-selenocystine and L-selenomethionine, on the $\left[{ }^{3} \mathrm{H}\right]$ thymidine incorporation. In the presence of cysteine and $\mathrm{BCS}$, selenocystine above $10^{-6} \mathrm{M}$ (as selenium) and selenomethionine above $5 \times 10^{-6} \mathrm{M}$ showed maximal effects. Without the additions of cysteine and $\mathrm{BCS}$, selenocystine and selenomethionine markedly enhanced the $\left[{ }^{3} \mathrm{H}\right]$ thymidine incorporation.

Table 2 shows viable cell densities at $48 \mathrm{~h}$ under different culture conditions. The densities increased markedly in cultures supplemented with cysteine plus BCS plus selenite (or selenocystine), and with $2 \mathrm{ME}$ respectively, correlating well with the results of $\left[{ }^{3} \mathrm{H}\right]$ thymidine incorporation labeled at $47 \mathrm{~h}$ (Figs. 2 and 3).

Cellular GSHPX activities. Table 2 also lists cellular GSHPx activities of the lymphocytes freshly prepared and those cultured for 2 days under different culture 


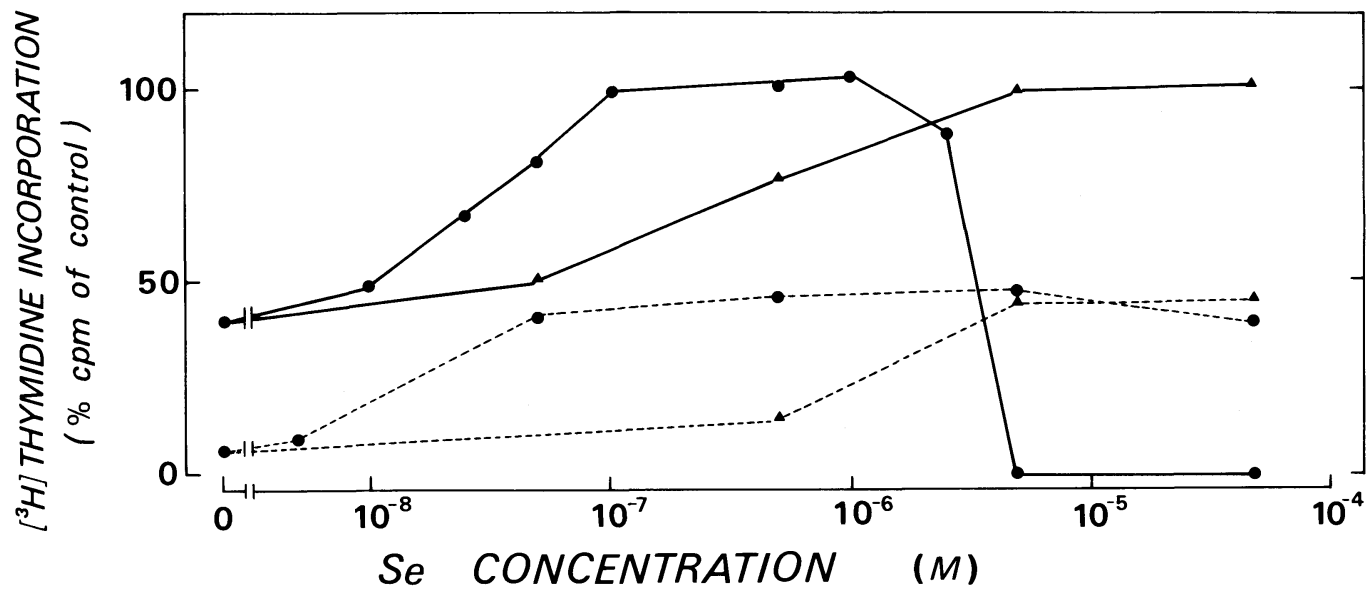

Fig. 2. Dose-dependent effects of sodium selenite $(\bullet)$ and sodium selenate $(\Delta)$, in the presence $(-)$ or absence (---) of cysteine $(100 \mu \mathrm{M} /$ every $12 \mathrm{~h})$ and BCS $(20 \mu \mathrm{M})$, on the $\left[{ }^{3} \mathrm{H}\right]$ thymidine incorporation. Values are expressed by $\% \mathrm{cpm}$ of the control $(+2 \mathrm{ME})$. Pulse-labeling was performed between 47 and $48 \mathrm{~h}$.

conditions. The enzyme activities per mg soluble cell protein decreased to 16 and $22 \%$ of the initial activity when cultured for 2 days with cysteine plus BCS, and with $2 \mathrm{ME}$, respectively. Since the GSHPx activity may indicate selenium status in the cells, this result suggests that the cells become deficient in selenium under those culture conditions. However, sodium selenite and selenocystine enhanced the enzyme activity only slightly.

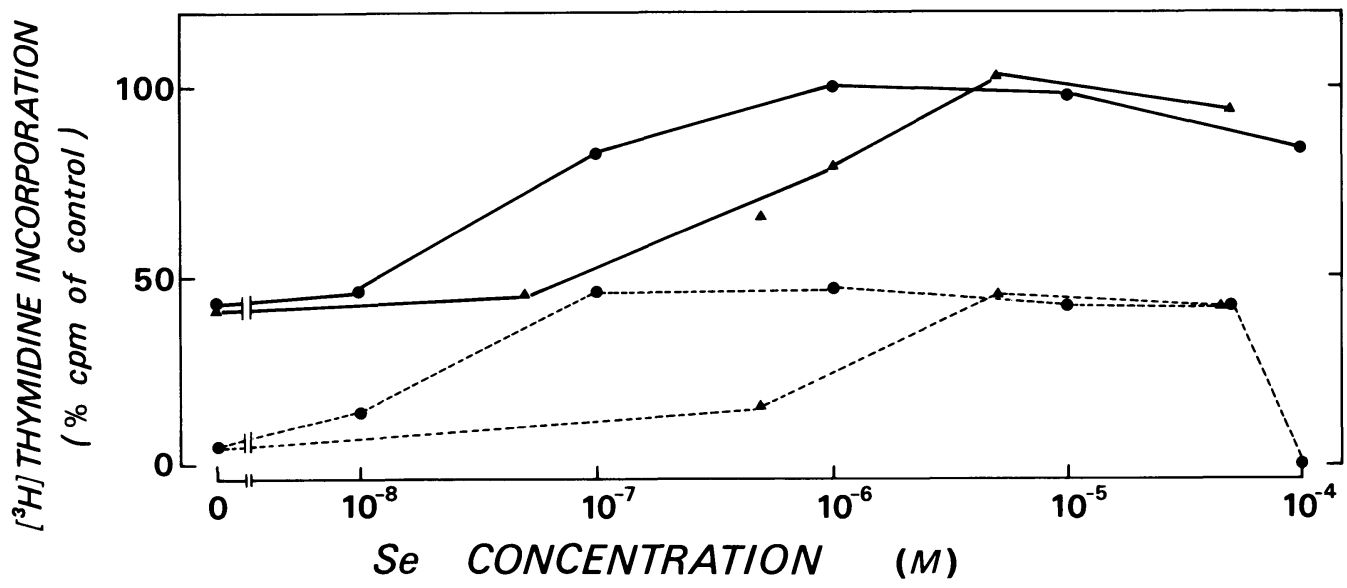

Fig. 3. Dose-dependent effects of selenocystine $(\bullet)$ and selenomethionine $(\Delta)$ in the presence $(-)$ or absence (---) of cysteine $(100 \mu \mathrm{M} /$ every $12 \mathrm{~h})$ and BCS $(20 \mu \mathrm{M})$, on the $\left[{ }^{3} \mathrm{H}\right]$ thymidine incorporation. Values are expressed by $\% \mathrm{cpm}$ of the control $(+2 \mathrm{ME})$. Pulse-labeling was performed between 47 and $48 \mathrm{~h}$. The molar concentration of selenocystine was doubled here since there are two Se per one molecule. 
TABLE 2. EFFECTS OF CYSTEINE (100 $\mu \mathrm{M} /$ EVERY $12 \mathrm{H})$ PLUS BCS $(20 \mu \mathrm{M})$, SODIUM SELENITE $\left(5 \times 10^{-7} \mathrm{M}\right)$, SElENOCYSTINe $\left(5 / 10^{-7} \mathrm{M}\right.$ AS SE), AND $2 \mathrm{ME}(20 \mu \mathrm{M})$ on CELlular GSHPX ACTIVITY AND ON CELL VIABILITY AND DENSITY AT $48 \mathrm{H}$ OF LPS-STIMULATED LYMPHOCYTES

\begin{tabular}{|c|c|c|c|c|}
\hline \multirow[b]{2}{*}{ Supplements } & \multicolumn{2}{|c|}{ GSHPx Activity ${ }^{\mathrm{a}}$} & \multirow{2}{*}{$\begin{array}{c}\text { Cell } \\
\text { Viability } \\
(\%)\end{array}$} & \multirow{2}{*}{$\begin{array}{c}\text { Viable } \\
\text { Cell Density } \\
\left(\text { cell } / \mathrm{ml} \times 10^{-6}\right)\end{array}$} \\
\hline & $\begin{array}{c}\text { Unit per mg soluble } \\
\text { cell protein }\end{array}$ & $\begin{array}{c}\text { Unit per } \\
10^{7} \text { viable cells }\end{array}$ & & \\
\hline$($ Fresh $0 \mathrm{~h})$ & $0.153 \pm 0.008$ & $0.020 \pm 0.008$ & $99 \pm 1$ & 1.0 \\
\hline \multicolumn{5}{|l|}{ (After $48 \mathrm{~h}$ ) } \\
\hline None & $0.048 \pm 0.008$ & $0.006 \pm 0.001$ & $69 \pm 7$ & $0.52 \pm 0.02$ \\
\hline Cys + BCS & $0.024 \pm 0.008$ & $0.008 \pm 0.002$ & $84 \pm 4$ & $0.86 \pm 0.02$ \\
\hline $\mathrm{Na}_{2} \mathrm{SeO}_{3}$ & $0.048 \pm 0.009$ & $0.013 \pm 0.002$ & $74 \pm 3$ & $0.72 \pm 0.15$ \\
\hline $\mathrm{Cys}+\mathrm{BCS}+\mathrm{Na}_{2} \mathrm{SeO}_{3}$ & $0.056 \pm 0.006$ & $0.020 \pm 0.001$ & $95 \pm 1$ & $1.46 \pm 0.32$ \\
\hline Selenocystine & $0.057 \pm 0.002$ & $0.016 \pm 0.003$ & $75 \pm 5$ & $0.68 \pm 0.12$ \\
\hline Cys + BCS + Selenocystine & $0.038 \pm 0.006$ & $0.014 \pm 0.002$ & $93 \pm 2$ & $1.41 \pm 0.19$ \\
\hline $2 \mathrm{ME}$ & $0.034 \pm 0.009$ & $0.010 \pm 0.005$ & $96 \pm 1$ & $1.60 \pm 0.08$ \\
\hline
\end{tabular}

Values are the means of three independent experiments ( \pm SEM).

a One unit $=0.5 \mu \mathrm{mol}$ NADPH oxidized per $\min$ at $25^{\circ} \mathrm{C}$.

Effects of $a$-tocopherol on DNA synthesis. Since $a$-tocopherol, a natural antioxidant, enhanced an in vitro immune response (5), we compared the effects of $a$ tocopherol on the DNA synthesis with those of selenite and 2ME. As shown in Table 3, $a$-tocopherol has an enhancing effect similar to that of selenite. The enhancing effect of $a$-tocopherol was saturated at about $1 \mu \mathrm{g} / \mathrm{ml}\left(2.3 \times 10^{-6} \mathrm{M}\right)$, and it was slightly less effective than selenite either in the presence or absence of cysteine plus BCS.

Variations among the serum lots. Table 4 summarizes the effects of 14 randomly selected lots of fetal bovine serum on the lymphocyte activation under different culture conditions. The second column indicates the relative incorporated radioactivity per culture in the presence of $2 \mathrm{ME}$. These values varied from 27 to $117 \%$ of the No. 1 lot (used in this report), suggesting that the activation varied widely with

TABLE 3. EFFECTS OF $\boldsymbol{a}$-TOCOPHEROL ON THE DNA SYNTHESIS OF LPS-STIMULATED LYMPHOCYTES IN THE PRESENCE OF ABSENCE OF CYSTEINE (100 $\mu \mathrm{M} / 12 \mathrm{H})$ AND BCS $(20 \mu \mathrm{M})$

\begin{tabular}{lcc}
\hline \multirow{2}{*}{ Supplements } & \multicolumn{2}{c}{$\begin{array}{c}{\left[{ }^{3} \mathrm{H}\right] \text { Thymidine Incorporation }(47-48 \mathrm{~h})} \\
(\% \mathrm{cpm} \text { of the control) }\end{array}$} \\
\cline { 2 - 3 } & without Cys and BCS & with Cys and BCS \\
\hline None & 9 & 44 \\
$a$-Tocopherol, $0.1(\mu \mathrm{g} / \mathrm{ml})$ & 13 & 56 \\
0.5 & 32 & 83 \\
1.0 & 38 & 88 \\
2.0 & 36 & 99 \\
$\mathrm{Na}_{2} \mathrm{SeO}_{3}\left(5 \times 10^{-7} \mathrm{M}\right)$ & 45 & \\
$2 \mathrm{ME}(20 \mu \mathrm{M})$ & 100 (control) & \\
$2 \mathrm{ME}+a$-Tocopherol $(2.0 \mu \mathrm{g} / \mathrm{ml})$ & 96 & \\
\hline
\end{tabular}

Values are calculated from the mean cpms of triplicate cultures.

a The incorporated radioactivity in the control samples labeled with $0.2 \mu \mathrm{Ci}\left[{ }^{3} \mathrm{H}\right]$ thymidine $(0.4 \mathrm{Ci} / \mathrm{m}$ mol) was $27427 \pm 864 \mathrm{cpm}$. 
TABLE 4. VARIATIONS AMONG FETAL BOVINE SERUM LOTS

\begin{tabular}{|c|c|c|c|c|c|c|c|}
\hline \multirow{4}{*}{$\begin{array}{l}\text { Serum } \\
\text { Lots } \\
\text { No. }\end{array}$} & \multicolumn{5}{|c|}{$\left[{ }^{3} \mathrm{H}\right]$ Thymidine Incorporation $(47-48 \mathrm{~h})$} & \multirow{4}{*}{$\begin{array}{c}\text { Selenium } \\
\text { content } \\
\mathrm{ng} / \mathrm{ml}\end{array}$} & \multirow{4}{*}{$\begin{array}{c}a-\text { Tocopherol } \\
\text { content } \\
\mathrm{ng} / \mathrm{ml}\end{array}$} \\
\hline & \multirow{3}{*}{$\begin{array}{c}2 \mathrm{ME} \\
\text { (cpm/culture) } \\
\% \text { of No. } 1 \text { lot }\end{array}$} & \multicolumn{4}{|c|}{ Ratios $\times 100$} & & \\
\hline & & None & $\mathrm{Se}$ & Cys, BCS & Cys, BCS, Se & & \\
\hline & & $2 \mathrm{ME}$ & $2 \mathrm{ME}$ & $2 \mathrm{ME}$ & $2 \mathrm{ME}$ & & \\
\hline 1. & 100 & $7 \pm 3$ & $43 \pm 5$ & $47 \pm 7$ & $99 \pm 4$ & 20 & 58 \\
\hline 2. & 89 & 8 & 37 & 39 & 88 & & \\
\hline 3. & 88 & 10 & 42 & 60 & 95 & 23 & 57 \\
\hline 4. & 97 & 11 & 36 & 53 & 94 & 19 & 43 \\
\hline 5. & 67 & 12 & 33 & 70 & 96 & & \\
\hline 6. & 56 & 13 & 27 & 68 & 96 & & \\
\hline 7. & 46 & 16 & 25 & 90 & 101 & & \\
\hline 8. & 60 & 18 & 35 & 80 & 93 & & \\
\hline 9. & 84 & 23 & 39 & 79 & 96 & & \\
\hline 10. & 103 & 25 & 44 & 73 & 90 & 15 & 53 \\
\hline 11. & 62 & 26 & 39 & 76 & 85 & & \\
\hline 12. & 27 & 26 & 30 & 81 & 93 & & \\
\hline 13. & 117 & 28 & 43 & 79 & 97 & 22 & 51 \\
\hline 14. & 92 & 28 & 42 & 71 & 93 & & \\
\hline \multirow[t]{3}{*}{15.} & 112 & 29 & 44 & 73 & 90 & & \\
\hline & & $19.5 \pm 7.7$ & $36.9 \pm 6.2$ & $70.9 \pm 13.0$ & $93.4 \pm 4.1$ & $19.8 \pm 3.1$ & $52.4 \pm 6.0$ \\
\hline & & \multicolumn{4}{|c|}{ Mean $\pm \operatorname{SEM}($ No. 2 to 15$)$} & \multicolumn{2}{|c|}{ (mean of 5 ) (mean of 5 ) } \\
\hline
\end{tabular}

Randomly selected serum lots (No. 2 to 15 ) from 4 companies were compared with the No. 1 lot (used in this report) for the effect of $\left[{ }^{3} \mathrm{H}\right]$ thymidine incorporation by LPS-stimulated lymphocytes. Each serum was heat-treated $\left(56^{\circ} \mathrm{C}\right.$ for $\left.30 \mathrm{~min}\right)$ and supplemented to the medium $\mathrm{Se}\left(\mathrm{Na}_{2} \mathrm{SeO}_{3}, 5 \times 10^{-7} \mathrm{M}\right)$ and $2 \mathrm{ME}$ $(20 \mu \mathrm{M})$.

the serum lot used. The third column indicates the enhancing effect of $2 \mathrm{ME}$, and the 14 serum lots were thus numbered accordingly. Supplementing $5 \times 10^{-7} \mathrm{M}$ selenite enhanced the $\left[{ }^{3} \mathrm{H}\right]$ thymidine incorporation in all serum lots. Cysteine plus BCS increased the incorporation rate from $19.5 \pm 7.7$ to $70.9 \pm 13.0 \%$ on average. Cysteine plus BCS plus selenite increased the incorporation rate up to $93.4 \pm 4.1 \%$ of that of 2ME. Table 4 also shows the selenium and $a$-tocopherol content of five serum lots. Because these contents did not differ significantly among the serum lots, they were not related to the variations between lots.

\section{DISCUSSION}

The results in this report show that $2 \mathrm{ME}$, which enhances proliferation of the mitogen-stimulated lymphocytes in vitro, can be fully replaced by two physiological substances, cysteine and a selenium compound. A single addition of $20 \mu \mathrm{M} 2 \mathrm{ME}$ was as effective as the repeated addition of $100 \mu \mathrm{M}$ cysteine every $12 \mathrm{~h}$ in the presence of $20 \mu \mathrm{M} \mathrm{BCS}$ and an appropriate concentration of a selenium compound. The action of $2 \mathrm{ME}$ as the carrier of cysteine has been established in L1210 cells (15) and confirmed in mouse spleen lymphocytes (26). As shown in Table 1, the enhancing effect of cysteine on the $\left[{ }^{3} \mathrm{H}\right]$ thymidine incorporation was saturated at physiological concentrations of cysteine, where it is evidenced that human and rat plasma contains $10-20 \mu \mathrm{M}$ cysteine $(20,28)$. Because the effect of selenium com- 
pounds is not apparently related to the transport of cysteine or cystine, $2 \mathrm{ME}$ must have another function in addition to that as a cysteine-carrier in enhancing DNA synthesis of the LPS-stimulated lymphocytes. this is a distinct difference in the $2 \mathrm{ME}$ requirement of lymphocytes from that of L1210 cells for cell proliferation.

It is confirmed that in the absence of $2 \mathrm{ME}$, relatively high concentrations of the selenium compounds are required for maximal enhancement of DNA synthesis of the mitogen-stimulated lymphocytes in an in vitro culture. The lymphocytes required $10^{-7}$ to $10^{-6} \mathrm{M}$ selenite for maximal effect, which was roughly one order of magnitude higher than that required by the human diploid fibroblast for maximal clonal cell growth (23). Usually, the selenium requirement of cultured cells is studied under a low content of serum because the serum contains selenium (23). The fetal bovine serum used in this study contained $20 \mathrm{ng} / \mathrm{ml}\left(2.5 \times 10^{-7} \mathrm{M}\right)$ selenium, with a value near the average of the 5 serum lots assayed (Table 4). Since the culture medium contained $10 \%(\mathrm{v} / \mathrm{v})$ serum, the selenium content in the medium, i.e., about $2.5 \times 10^{-8} \mathrm{M}$, seems insufficient to support the DNA synthesis of the lymphocytes, although it is unknown what types of selenium compounds are included in the serum. It should be noted that the serum lots showed variable selenium dependence, as shown in Table 4, although their contents of selenium and $a$ tocopherol did not differ greatly. This may suggest that the sera contain another factor(s) which alters the effect of selenium compounds.

The dependence of immune responses on selenium has been extensively studied in experimental animals. Berenshtein (2) first reported a potentiation of humoral immunity by selenium. Rabbits, in which sodium selenite was administered, produced higher antibody titers against a typhoid vaccine than control rabbits fed a seleniumdeficient diet. Spallholz et al. $(30,31)$ reported that dietary or intraperitoneally injected selenite enhanced antibody titers as well as the number of antibody producing cells against sheep red blood cells in mice. The similar effect of dietary selenite on immunity was reported in chicks (22). In the in vitro culture system, lymphocyte activation in response to mitogens decreased in animals fed diets deficient in selenium, as reported in the study of peripheral lymphocytes from pigs (19) and dogs (29), and spleen lymphocytes from rats (10). In those in vitro experiments, however, the effects of selenium compounds during activation were not examined. The results of this report indicate that in the activation of normal spleen lymphocytes with LPS, the selenium requirement appears after $24 \mathrm{~h}$ in culture. In the presence of cysteine and BCS, adding selenite either at $0 \mathrm{~h}$ or $24 \mathrm{~h}$ in culture shows almost the same enhancement effect when the $\left[{ }^{3} \mathrm{H}\right]$ thymidine incorporation is measured at $47 \mathrm{~h}$ (data not shown). This may suggest that oxidative damage may gradually be accumulated within the lymphocytes, or that the lymphocytes may gradually be deficient in selenium, as implied by the fact that intracellular GSHPx activity decreases during the culture period (Table 2 ).

$a$-Tocopherol is also important in immune responses in vivo and in vitro. Tengerdy et al. showed that $a$-tocopherol used as a diet supplement enhanced the immune responses in chicks (32) and also in mice (33). Campbell et al. (5) showed that $a$ tocopherol was as effective as $2 \mathrm{ME}$ in enhancing the immune responses of normal spleen lymphocytes in vitro. Their result is apparently inconsistent with ours. In our assay system, $a$-tocopherol was far less effective than $2 \mathrm{ME}$ if cysteine was not supplemented (Table 3). This discrepancy may be elucidated by the differences of the assay conditions. First, Campbell et al. (5) cultured the cells under a high-cell density and a low-oxygen tension (8.5\%). These conditions may reduce the requirement 
of cysteine supply. Second, they counted the number of antibody-producing cells after 5 days in culture, but they did not monitor the early phase of the immune response.

The important finding in this report is that both the selenium compounds and $a$ tocopherol enhance DNA synthesis in a manner different from that of cysteine. It is noted that a selenium compound is still required by the cells containing sufficient amounts of cellular cysteine and GSH; adding $100 \mu \mathrm{M}$ cysteine every $12 \mathrm{~h}$ in the presence of BCS is sufficient to maintain high intracellular GSH levels on the second day (data not shown). In this assay system, the antioxidant activity of selenium compounds may not be elucidated by the cellular GSHPx because selenite and selenocystine were not effective in maintaining GSHPx activity (Table 2). Also, it cannot be determined at present how $2 \mathrm{ME}$ at $10^{-5} \mathrm{M}$ functions in a manner similar to selenium compounds. Further studies on these problems should elucidate the mechanism of the action of selenium in enhancing DNA synthesis of the lymphocytes.

Acknowledgments. We are grateful to Mr. T. Nakamura and Mr. I. Hishinuma (Eisai) for measuring the $a$-tocopherol contents in the sera, and to Dr. K. Soda for providing L-selenocystine. This work was supported, in part, by grants from the University of Tsukuba Project Research and the Special Research Project on Metabolism from the Ministry of Education.

\section{REFERENCES}

1. AвE, K. and G. Katsui. Determination of tocopherols in serum by high speed liquid chromatography. Vitamins 49, 259-263, 1975 (in Japanese)

2. Berenshtein, T.F. Effect of selenium and Vitamin $\mathrm{E}$ on antibody formation in rabbits. Zdrawookhr Boloruss. 18, 34-41, 1972

3. Broom, J.D. and M.W. Jeng. Promotion of replication in lymphoid cells by specific thiols and disulfides in vitro. J. Exp. Med. 138, 574-592, 1973

4. Burger, M., M.W. Hess and H. Cottier. The role of 2-mercaptoethanol in the stimulation of spleen cell cultures: increased uptake of cystine into the TCA-soluble pool. Immunol. Letters. 4, 193-197, 1982

5. Campbell, P.A., H.R. Cooper, R.H. Heinzerling and R.P. Tengerdy. Vitamin E enhances in vitro immune response by normal and nonadherent spleen cells. Proc. Soctr. Exp. Biol. Med. 146, 465-469, 1974

6. ChEn, C. and J.G. Hirsch. The effects of mercaptoethanol and of peritoneal macrophages on the antibody-forming capacity of nonadherent mouse spleen cells in vitro. J. Exp. Med. 136, 604-617, 1972

7. Click, R.E., L. BeNCH and B.J. Alter. Enhancement of antibody synthesis in vitro by mercaptoethanol. Cell. Immunol. 3, 156-160, 1972

8. De Jong, B. and I.H. Van der Mear. Augmentation of Chinese hamster lymphocyte stimulation by cysteine. J. Immunol. Method. 68, 55-60, 1984

9. Esaki, N., H. Tanaka, E.W. Miles and K. Soda. Enzymatic synthesis of Se-substituted Lselenocysteine with tryptophan synthase. FEBS lett. 161, 207-209, 1983

10. Eskew, M.L., R.W. Scholz, C.C. Raddy, D.A. Todhunter and A. Zarkower. Effects of vitamin $\mathrm{E}$ and selenium deficiencies on rat immune function. Immunology. 54, 173-180, 1985

11. Fanger, M.W., D.A. HaRT, J.V. Wells and A. Nisonoff. Enhancement by reducing agents of the transformation of human and rabbit peripheral lymphocytes. J. Immunol. 105, 1043-1045, 1970

12. Hishinuma, I., T. Ishin, H. Watanabe and S. BannaI. Mouse lymphoma L1210 cells acquire a new cystine transport activity upon adaptation in vitro. In Vitro. 22, 127-134, 1986

13. Hornsby, P.J., D.W. Pearson, A.P. Autor, K.A. Aldern and S.E. Harris. Selenium deficiency in cultured adrenocortical cells: restoration of glutathione peroxidase and resistance to 
hydroperoxides on addition of selenium. J. Cell. Physiol. 123, 33-38, 1985

14. Ishit, T., I. Hishinuma, S. BannaI and Y. Sugita. Mechanism of growth promotion of mouse lymphoma L1210 cells in vitro by feeder layer or 2-mercaptoethanol. J. Cell. Physiol. 107, 283293, 1981

15. IsHII, T., S. BANNAI and Y. SugitA. Mechanism of growth stimulation of L1210 cells by 2-mercaptoethanol in vitro: role of the mixed disulfide of 2-mercaptoethanol and cysteine. J. Biol. Chem. 256, 12387-12392, 1981

16. IshiI, T., T. Todoroki, A. TAKadA and Y. Sugita. Mouse lymphoma L1210 cells can be arrested in the $G_{1}$ phase by adjusting cellular cysteine and glutathione. Cell Struct. Funct. 10, 89-93, 1985

17. IsHII, T. and S. BANNAI. The synergistic action of the copper chelator bathocuproine sulphonate and cysteine in enhancing growth of L1210 cells in vitro. J. Cell Physiol. 125, 151-155, 1985

18. IshiI, T., Y. Sugita and S. BannaI. Regulation of glutathione levels in mouse spleen lymphocytes by transport of cysteine. J. Cell. Physiol. 133, 330-336, 1987

19. Larsen, H.J. and S. TollersRud. Effect of dietary vitamin E and selenium on the phytohaemagglutinin response of pig lymphocytes. Res. Vet. Sci. 31, 301-305, 1981

20. LASH, L.H. and D.P. Jones. Distribution of oxidized and reduced forms of glutathione and cysteine in rat plasma. Arch. Biochem. Biophys. 240, 583-592, 1985

21. Lowry, O.H., N.J. Rosenbrough, A.L. Farr and R.J. Randall. Protein measurement with the folin phenol reagent. J. Biol. Chem. 193, 265-275, 1951

22. Marsh, J.A., R.R. Dietert and G.F. Jr. Comb. Influence of dietary selenium and vitamin $\mathrm{E}$ on the humoral immune response of the chick. Proc. Soc. Exp. Biol. Med. 166, 228-236, 1981

23. McKeehan, W.L., W.G. Hamitton and R.G. Ham. Selenium is an essential trace nutrient for growth of WI-38 diploid human fibroblasts. Proc. Natl. Acad. Sci. USA. 73, 2023-2027, 1976

24. Mohindru, A., J.M. Fisher and M. Robinoviz. Endogeneous copper is cytotoxic to a lymphoma in primary culture which requires thiols for growth. Experientia. 41, 1064-1066, 1985

25. OHMORI, H. and I. Yамамото. Mechanism of augmentation of the antibody response in vitro by 2-mercaptoethanol in murine lymphocytes. I 2-mercaptoethanol-induced stimulation of the uptake of cystine, an essential amino acid. J. Exp. Med. 155, 1277-1290, 1982

26. ОнмоRI, H. and I. Yамамото. Mechanism of augmentation of the antibody response in vitro by 2-mercaptoethanol in murine lymphocytes. II A major role of the mixed disulfide between 2-mercaptoethanol and cysteine. Cell. Immun. 79, 173-185, 1983

27. Paglia, D.E. and W.N. Valentine. Studies on the quantitative and qualitative characterization of erythrocyte glutathione peroxidase. J. Lab. Clin. Med. 70, 158-169, 1967

28. SaEtre, R. and D.L. Rabenstein. Determination of cysteine in plasma and urine and homocysteine in plasma by high-pressure liquid chromatography. Anal. Biochem. 90, 684-692, 1978

29. ShefFy, B.E. and R.D. Schultz. Nutrition and the immune response. Cornell Vet. 68 (suppl. 7), 48-61, 1978

30. Spallholz, J.E., J.L. Martin, M.D. Gerlach and R.H. heinzerling. Enhanced immunoglobulin $\mathrm{M}$ and immunoglobulin $\mathrm{G}$ antibody titers in mice fed selenium. Infec. Immunity. 8, 841-842, 1973

31. Spallholz, J.E., J.L. Martin, M.L. Gerlach and R.H. Heinzerling. Immunologic responses of mice fed diets supplemented with selenite selenium. Proc. Soc. Exp. Med. Biol. 143, 685-689, 1973

32. Tengerdy, R.P., R.H. Heinzerling and C.F. Nockels. Effect of vitamin E on the immune response of hypoxic and normal chickens. Infect. Immun. 5, 987-989, 1972

33. Tengerdy, R.P., R.H. Heinzering, G.L. Brown and M.M. Mathias. Enhancement of the humoral immune response by vitamin E. Int. Arch. Allergy. 44, 221-232, 1973

34. Watanabe, H. and S. Bannai. Induction of cystine transport activity in mouse peritoneal macrophages. J. Exp. Med. 165, 628-640, 1987

35. ZmudA, J. and B. Friedenson. Changes in intracellular glutathione levels in stimulated and unstimulated lymphocytes in the presence of 2-mercaptoethanol or cysteine. J. Immunol. 130, 362364,1983 